\section{Questión}

Periodismo / Comunicación ISSN 1669-6581

La voz en la radio

Claudia Díaz

Question/Cuestión, Vol. 2, N 66, Agosto 2020

ISSN 1669-6581

https://perio.unlp.edu.ar/ojs/index.php/question/index

IICom-FPyCS-UNLP

\title{
LA VOZ EN LA RADIO
}

\section{THE VOICE ON THE RADIO}

\section{Claudia Díaz}

Docente en la carrera de Locución FPyC Licenciada en Fonoaudiología claudiadiaz85@hotmail.com

\section{Resumen}

Claudia Díaz explora la voz, en la formación de los locutores, en el habla. Reconoce subjetividades y enfoca forma y contenido. Se pregunta y cuestiona. El entrenamiento de la escucha holística. Trabajar la foniatría para potenciar una mejor claridad de enunciación y respetar las identidades profesionales.

\section{Palabras clave}

Radio, Locución, Voz, Identidad, Subjetividad 


\section{Abstract}

Claudia Díaz explores the voice, in the formation of the announcers, in speech. Recognize subjectivities and focus on form and content. He wonders and questions. Holistic listening training. Work on speech therapy to enhance clarity of enunciation and respect professional identities.

\section{Keywords}

Radio, Locution, Voice, Identity, Subjectivity

\section{Enlace a video}

https://youtu.be/2kwHzO7HLaE 